\title{
Rhetoric and History in Service of Education in Poland on the Basis of the Script of Rhetoric Lectures at the Jesuit College in Poznań from 1679
}

\begin{abstract}
Rhetoric was the most important subject of the Old Polish educational system, with its roots tracing back to the tradition of the Ancient Rome. The statement itself is crucial, due to the fact of the orator's moral and patriotic duties. Therefore, the lectures were focused not only on the technical aspects of rhetoric, but also on morality, religion and political knowledge.

The article consists of two main sections. The first section is dedicated to describing the role of the rhetorical education, as well as, the evolution of the relation between rhetoric and history, which had existed from the $1^{\text {st }}$ century A.D. until the first decades of the $18^{\text {th }}$ century, when history began to separate from rhetoric.

The second section is dedicated to presenting the history education in practice, on the example of the Jesuit college in Poznań. The analysis of the matter is based on the script of rhetoric lectures given in Poznan in 1679. With regard to the aforementioned manuscript, one could say, that the most important task of history education, was the patriotic and civil upbringing of pupils, so that they could participate in political and cultural activities. History taught at the College in Poznań was mainly dedicated to Poland, and was of practical nature.
\end{abstract}

Keywords: history of education, Jesuit College in Poznan, $16^{\text {th }}-18^{\text {th }}$ century Poznan school system, secondary schools, history education, moral values

History in Polish schools of the Old Polish period played a supportive role and was rarely taught as a separate component of the curriculum. However, that does not mean that its role was limited. Quite the contrary. History always constituted an effective vessel of didactic content of educational character, particularly in the scope of civil education. The article presents the supportive role of history, in the practice of educating school youth in the Old Polish period. In order to provide the most comprehensive overview of the phenomenon the reference material has been narrowed down to a particular example: the Jesuit College in Poznań, one of the most significant colleges in the Republic of 
Poland. For the analysis of the issue, one of the rhetorical scripts was treated with particular care, one coming from the aforementioned college, from $1679^{1}$. Obviously, the abovementioned role of history in the process of education is already well known and described in historiography ${ }^{2}$, here however, we shall present the practical application of this subject, in a particular centre of education. A brief sketch will serve as an introduction, presenting the relation between history and rhetoric, having been born since antiquity.

Already in the Renaissance, it was noted that history provides an excellent ground for shaping the personalities of youth. As Lech Mokrzecki noted, the role of history in Old Polish schooling consisted of illustrating, via examples, the principles formed theoretically by ethics. Philosophy and ethics were to prepare the principles of proceeding, history however, were to illustrate them with proper examples. Moreover, history was to serve the purpose of revealing the legitimacy of promoted principles and the negative results of their rejection ${ }^{3}$. Its role in education was no coincidence. Obviously, the examples presented during classes were selected for the purpose of achieving the greatest educational effect. Therefore, one of the primary tasks of history, was to present the adequate models of proceeding, i.e. an effective and ethical activity in the political, religious and economical planes ${ }^{4}$.

As it is known, the central place in Old Polish education was taken by rhetoric, which was highly criticised in bygone literature ${ }^{5}$. Regardless of the opinion on the phenomenon, one should note a number of essential aspects that had a decisive influence on the formation of Old Polish education curricula ${ }^{6}$. The Renaissance world, very early began to refer to the antique tradition, not only regarding philosophy, literature, or art, but also regarding education. Within the scope of education, the final phase was constituted by rhetoric, an art born in Greece, in time translated to the Roman grounds, and adjusted to the needs of the Roman Empire. Although, the entire theory of rhetoric, was born in the Hellenic world, the Renaissance schools, as well as later ones, would employ Roman theories, which is understandable, considering the community of language. Two characters play a decisive role here: Cicero and Quintilian. The primary contribution of the former was

\footnotetext{
${ }^{1}$ Capitolium Copiose loquentis sapiae Avitis Poloniae Nobilitatum Stemmatibus Ceris fumosisque Maiorum illustre imaginibus Oratorum Calamo Ingenioque adumbratum ac Konarsciano in Academo Arhitectante Eloquentiae manu erectum ac reseratum Anno [...], 1679, Biblioteka Uniwersytecka w Poznaniu, MS 588 I.

2 Within the context of the following article, one should particularly mention: PUCHOWSKI, K., Edukacja historyczna w jezuickich kolegiach Rzeczypospolitej 1565-1773, Gdańsk 1999.

${ }^{3}$ MOKRZECKI, L., Początki nauczania historii w okresie I Rzeczypospolitej na tle praktyki stosowanej w szkolnictwie europejskim, [in:] Wokół staropolskiej nauki i oświaty. Gdańsk-Prusy Królewskie-Rzeczpospolita, Gdańsk 2001, p. 396.

${ }^{4}$ However, one should remember, that exercising the history curriculum in the Old Polish period, particularly until the half of the $18^{\text {th }}$ century, each time had been dependent on the preference and the factual knowledge of the professors.

5 See e.g.: ŁUKASZEWICZ, J., Historya szkół w Koronie $i$ w Wielkiem Księstwie Litewskiem od najdawniejszych czasów aż do roku 1794, Poznań 1849, vol. 1-3.

6 The author intentionally uses this generalising term, due to the visible community of accomplished tasks, methods and, to a high degree, methods, of education.
} 
the creation of a technical language, the rhetorical Latin, as well as leaving behind an impressive legacy. In turn, the latter, provided a very precise presentation of the method of teaching rhetoric, as well as, characterised the antique model of an orator. One should examine him closer, as he reveals the meaning of rhetorical education altogether, including the Old Polish period. The orator, aside from unquestionable oratory skill and an appropriate technical training, should also possess comprehensive knowledge, and above all, should be a righteous man (vir bonus) ${ }^{7}$. We should also mention, that according to both mentioned theorists of speech, history was of considerable significance in the education of a future orator ${ }^{8}$. According to Cicero, the role of history was by no means limited to gathering examples useful in composing speeches. Wide erudition should provide the future orator with the knowledge of human nature, characteristic human defects: ambition and passion, as well as virtues: moderation and modesty, as well as such aspects as pain and death $^{9}$. Additionally Cicero highlighted the significance of the knowledge of law (regarding war, peace, taxes and in general - civil law), tradition and religion ${ }^{10}$, as well as indicated the advantages resulting from philosophical studies, to which he drew special attention $^{11}$. Referring to Cicero's theory in this matter is entirely justified, as students of Old Polish schools, would usually study it thoroughly, particularly the work On the Orator. Additionally, other philosophical works of Cicero also enjoyed popularity, e.g. On Duties and On Old Age, which presented the canon of virtues and civil duties, considered as appropriate $^{12}$.

Rhetorical education in Old Polish school system ensured the preparation of youth for public life, both in terms of political and literary culture. Aside from presenting students with knowledge and oratory skills, useful in future practice, school youth was also prepared to the active and passive participation in the cultural life of the era ${ }^{13}$. The pragmatism of education in this model, is striking.

${ }^{7}$ QUINTILIANUS, M.F., Institutionis oratoriae libri XII, ed. L. RADERMACHER, in Aedibus B.G. Tevbneri, Lipsiae 1959, p. 4: Oratorem autem instituimus illum perfectum, qui esse nisi vir bonus non potest, ideoque non dicendi modo eximiam in eo facultatem, sed omnis animi virtutes exigimus; p. 6: Sit igitur orator vir talis, qualis vere sapiens appellari possit, nec moribus modo perfectus [...] sed etiam scientia et omni facultate dicendi.

${ }^{8}$ See, e.g.: CICERO, M.T., De oratore ad Q. fratrem, Oxoniae post 1697, p. 50; p. 58; p. 83 et al.

9 Ibidem, p. 21

${ }^{10}$ Ibidem, p. 13: "Quid? Leges veteres, moresque maiorum,: quid? Auspicia, quibus \& ego, \& tu, Crasse, cum magna Reipublicae salute praesumus: quid? Religiones, \& ceremoniae: quid? Haec jura civilia, quae jam pridem in nostra familia ulla eloquentiae laude versantur [...]”; p. 19.

11 Ibidem, p. 14 et al.

12 BIEŃKOWSKI, T., Antyk w literaturze i kulturze staropolskiej (1415-1750). Główne problemy i kierunki recepcji, Wrocław-Warsaw-Kraków-Gdańsk 1975, p. 51.

13 BIEŃKOWSKI, T., Ksztaltowanie publiczności literackiej $w$ szkołach $w$ Polsce w XVI i XVII w., [in:] Publicznośc literacka i teatralna $w$ dawnej Polsce, ed. H. DZIECHCIŃSKA, Warsaw-Lódź 1985, p. 39-49; Idem, Szkolne wykształcenie retoryczne wobec wymogów praktyki (Uwagi o funkcji retoryki w Polsce $w$ XVI i XVII w.), [in:] Retoryka a literatura, ed. B. OTWINOWSKA, Wrocław 1984, p. 212 et al. 
The curriculum shaped gradually in the $16^{\text {th }}$ and the $17^{\text {th }}$ centuries, expanding on the Renaissance vision of the human firmly grounded in the social dimension, and strongly tied to the world of nature (perceived realistically and studied scientifically), with the spiritual dimension, resulting with the Sturmian effect of sapiens atque eloquens pietas, along with simultaneous pragmatic of teaching ${ }^{14}$. As noted by Bednarski: "speech perceived as such, served simply as a way of life", as its task was to teach "managing the situation and finding the appropriate practical position, and the appropriate view regarding a particular thing" 15 , which is in accordance with the aforementioned advice from Cicero.

Examining the $16^{\text {th }}$ century education practice in Poland, we come to a conclusion that within the first half of the century, history primarily served menial tasks of supporting rhetoric, where eloquence would be set in the foreground, history however, was to provide the necessary erudition to fill the speech with content. Aside from that, one may notice its didactic function derived from the need for explaining the matters discussed in schools, drawing upon classic works ${ }^{16}$. However, in the second half of the century, the main educational tasks changed slightly, and the emphasis was transferred again to moral, or in broader strokes, religious education, albeit with the consideration of the educational needs of nobility ${ }^{17}$. In time, the application of history would be expanded on poetics, literature, politics, and particularly on ethics, where the role of history, as a treasury of various examples, is exhibited ${ }^{18}$. Already in the $16^{\text {th }}$ century, one may notice the clear employment of historical content not only as exemplification material, but also for the purpose of strictly educational tasks, in regard to moral or patriotic education. Let us mention the historical work of Klemens Janicki, in which the attempts of educational influence on the reader are made explicit ${ }^{19}$. In the $17^{\text {th }}$ century, the position of history in schools solidified, however, the scope of the curriculum was mostly dependent on the professor. However, at times, history would stand apart as an independent component of the curriculum, often related to rhetoric ${ }^{20}$. In Poznań, such situation occurred in the case of the Lubrański Academy,

14 PREJS, M., Humanizm potrydencki i nowy model kultury katolickiej (manieryzm czy bark?), [in:] Humanistyczne modele kultury nowożytnej wobec dziedzictwa starożytnego, ed. M. PREJS, Warsaw 2010, p. 157.

15 BEDNARSKI, S., Upadek i odrodzenie szkół jezuickich w Polsce, Kraków 1933, p. 185.

16 Ibidem, p. 254.

${ }^{17}$ One should note, that the needs had intentionally been satisfied by Jesuits since the very first years of the schools' functioning in the Republic, see: PIECHNIK, L., Działalność jezuitów polskich na polu szkolnictwa (1565-1773), [in:] Jezuici a kultura polska, ed. L. GRZEBIEŃ and S. OBIREK, Kraków 1993, s. 246 et al.

18 MOKRZECKI, L., Poczatki nauczania historii..., op. cit., p. 390-403.

19 JANICKI, K., Vitae Regum Polonorum elegiaco carminae descriptae, Kraków 1569. According to: PUCHOWSKI, K., Edukacja historyczna..., p. 82. Vitae Regum Polonorum received much interest in Jesuit schools, already in the Enlightenment period.

${ }^{20}$ A widespread phenomenon nationwide, see e.g. 
a matter known, owing to the Canonical visitation of bishop Wojciech Tolibowski from $1660^{21}$.

The history curriculum in Poland was shaped primarily due to the initiative of bishop Piotr Tylicki, who instructed to formulate adequate dispositions, primarily for the needs of parish and cathedral schools. Stanisław Kot described the significant dispositions of the Modus Instituendae Iuventutis in the following words: "One may first study history from Justin, who derives the beginnings of the Republic from the creation of the world, followed by Florus, as a summary of the Roman history of Livy, and one should not omit Curtius for the curious, picturesque language and favourable narrative; older students could include Sallust. Not to omit the matters of the country, aside from the mentioned, one should read Janicki's poem on the Polish history and the history by Herburt. From the reading one should write down examples, wise sayings and memorable deeds"22. However, in terms of execution, the curriculum was to a significant degree dependent on the factual knowledge preparation of the professors, it provides a general overview of historical content presented in schools.

Following this rather brief overview, we shall turn to the issue of the place of history in Jesuit education. Particularly interesting, are the Jesuit methods of teaching, developed long and meticulously, drawing upon the previous achievements, starting with the Brethren of the Common Life ${ }^{23}$. However, it was the long lasting educational practice, who intentionally perfected the methodological premises of their school system, that were decisive for the shaping of the aforementioned methods. The result of the effort, was the famous Ratio studiorum, regulating the methods of work and the scope of the curriculum exercised within schools, in detail ${ }^{24}$.

The act regarded historical education, as a late entry into the curriculum, following the proper linguistic preparation of the students. Historical education was to be initiated in humanities classes (also regarded as poetics). Erudition should be learned by reading orators, historians and poets ("purified" of all indecencies). Orators were to be represented by Cicero and his moral orations as well as simpler ones, such as: In favour of the Lex Manilia, In defence of Archias, On behalf of Marcellus, or other orations directed at Caesar; historians were to be represented by: Caesar, Sallust, Livy, Curtius et al.; poets by: Virgil (excluding the Eclogues and the fourth book of the Aeneid), selected odes by Horace, as well as elegies, epigrams and other works by the representatives of the lit-

${ }^{21}$ Akta wizytacji 1660-1663, The Archdiocesan Archive in Poznań, sign. AV 12, p. 112: “Andreas Stanislaus Idecki orator legit mane duabus horis et duabus post meridiem Lectiones facultatis Oratoriae et Historiae."

${ }^{22}$ KOT, S., Szkolnictwo parafialne w Małopolsce XVI-XVIII w., Lwów 1912, p. 54.

${ }^{23}$ See, e.g.: NATOŃSKI, B., Szkolnictwo jezuickie $w$ Polsce $w$ dobie kontrreformacji, [in:] Wiek XVIIKontrreformacja-Barok. Prace z historii kultury, ed. J. PELC, Wrocław 1970, p. 35.

${ }^{24}$ In the article, we shall employ the following edition: Ratio atque institutio studiorum Societatis Iesu, Romae 1616. See, also the Polish ed.: Ratio atque institutio studiorum SJ czyli Ustawa szkolna Towarzystwa Jezusowego (1599), ed. K. BARTNICKA, Warsaw 2000; as well as literature regarding the act: PIECHNIK, L., "Ratio studiorum": fundament działalności edukacyjnej i naukowej jezuitów, [in:] Wkład jezuitów do nauki i kultury w Rzeczpospolitej Obojga Narodów i pod zaborami, ed. I. STASIEWICZ-JASIUKOWA, Kraków 2004. 
erary antiquity. In regard to erudition, a remark was made, that it should stimulate the skills of students and bring relief, rather than stand in the way of mastering the language. Therefore, the teacher should exhibit moderation in the matter ${ }^{25}$.

In practice, in the first semester the teacher would dedicate a certain separate part of the curriculum to discuss a historical writer. Through the half of the semester, the dedicated time (half an hour) would be shared among the metrical art, later on it would be dedicated solely to history. Additionally, erudite remarks could appear during the Latin lecture, given to students, however, one should exhibit moderation in the matter, and exercise it only at the time of need. A fact worth noting is that, however, the main history curriculum was appointed to poetics and rhetoric classes, fragmentary knowledge regarding the subject was usually passed earlier, during the study of antique languages.

In the school of rhetoric the works of historians and poets were to serve the purpose of exemplification of the employment of a particular style of rhetorical principle. Additionally, the erudition of students regarding the "history and customs of various nations, and the statements of writers and all sciences" was meant to be passed to students, however according to the progress of a particular class. The most comfortable time for that, was a time of break and Saturdays, when readings and explanations of historians, poets and other authors would commence. A plethora of subject would appear during these lessons, including the Roman and Athenian senate, the military of the aforementioned, the garden art, clothing, dining customs, triumph, oracle, with one restriction: to exercise moderation. Additionally, at the end of the school year, an author whose works exhibited greater knowledge and variety, could be presented. The possibility of expanding the historical erudition would appear, additionally during the lecture on the principles, where aside from exemplification one could draw upon additional issues regarding history or other disciplines, as well as, during the lecture regarding a selected speech. In the above case, the teacher should recall the opinions of wise men regarding the discussed matter or draw upon sources to further embellish the subject: from history, mythology, and other sources. Additionally a number of Greek lectures in the first semester would be dedicated to the discussion regarding historical writers.

The considerable significance and the strong position of history within Ratio studiorum, are indubitable, however, its role in this act, seems to have been reduced to erudition and exemplification. The technical nature of the appropriate act paragraphs may have been an influence at hand here, as obviously, the educational aims of the Jesuit schools were far from erudite. One should note, that erudition was to serve the purpose of providing entertainment and adding pleasantry to a lesson, but also, to stimulate the mind $^{26}$.

In time, history managed to establish a firm position in the schools of the Society of Jesus, and in the $17^{\text {th }}$ century, new postulates appeared, regarding separation history class-

\footnotetext{
${ }^{25}$ See, the prescriptions in Ratio studiorum for particular schools and their professors.

${ }^{26}$ Ratio atque institutio studiorm Societatis Iesu..., op. cit., p. 122-128: Regulae Professoris Humanitatis; See also: BEDNARSKI, S., Upadek i odrodzenie..., op. cit., p. 254 et al.
} 
es (Vilnius Academy), denied by the Chapter General. So far, history had to be presented within the framework of other humanities ${ }^{27}$.

Regardless of the fact, that the history of Poland had been present in these walls until the end of the $16^{\text {th }}$ century, limiting the antique curriculum for the sake of the contemporary proceeded slowly, in result of the gradual polonisation of the teaching $\operatorname{staff}^{28}$. The central points of interest contained such aspects as: power, state, law, military, religion. Changes of much more dynamic nature can be observed in the $18^{\text {th }}$ century, however, they remain outside our interest ${ }^{29}$.

Regarding the fact, that history constituted an essential component of rhetorical education, province authorities often gave attention to the appropriate education of students within the subject. In this context, Ludwik Piechnik would recall one of the instructions, ordering to put particular emphasis on the youth to give themselves into "an honest study of history, mathematics, geometry and speech", while the colleges were obligated to provide schools with suitable handbooks, helpful in studying ${ }^{30}$.

In the didactic process of teaching rhetoric, the Jesuit education employed antique rhetoric treatises: Aristotle, Cicero and Quintilian, as well as contemporary works, particularly the compendium by Cypriano de Soarez titled De arte rhetorica libri tres, acclaimed throughout Europe. Since the half of the $17^{\text {th }}$ century, Jesuits in the Republic also had the rhetorical compendium by Zygmunt Lauxmin titled Praxis oratoria, at their disposal. These handbooks, however containing the theory of rhetoric, were filled with various historical facts, employed on numerous occasions. Their purpose was to present examples of employing a particular rhetorical principle, however selected in such way, as to provide additional factual knowledge, or even exert certain educational influence. Let us look at the example of the Praxis oratoria handbook ${ }^{31}$ :

- p. 15: Nam si potest ista pecunia sine Aratorum injura detrahi. Populus Romanus habeat: Praesertim in tantis aerarij angustijs.

- p. 16: - p. 16: Hoc capito QUIRITES omnes Gentes, Nationes, Provincias, Regna, Decemvirum ditioni, judicio, potestatique permissa et condonata esse dico. [...] Nisi ut decem

27 MOKRZECKI, L., PUCHOWSKI, K., Pierwsi nauczyciele historii w szkolnictwie staropolskim, [in:] Nauczyciel historii. Ku nowej formacji dydaktycznej, ed. M. KUJAWSKA, Poznań 1996, p. 12; PUCHOWSKI, K., Edukacja historyczna..., op. cit., p. 53 et al.

${ }^{28}$ PUCHOWSKI, K., Edukacja historyczna..., op. cit., p. 57 et al.; regarding the Polish elements in teaching history see: BIEŃKOWSKI, T., "Bibliotheca selecta de ratione studiorum” Possevina jako teoretyczny fundament kultury kontrreformacji, [in:] Wiek XVII - Kontrreformacja..., op. cit.

29 See, e.g.: PUCHOWSKI, K., Edukacja historyczna..., op. cit., p. 142 et al.; PIECHNIK, L., Przemiany w szkolnictwie jezuickim w Polsce XVIII wieku, [in:] Z dziejów szkolnictwa jezuickiego w Polsce: wybór artykułów, ed. J. PASZENDA, Kraków 1994, p. 191-194.

30 PIECHNIK, L., Przemiany w szkolnictwie..., op. cit., p. 207.

31 LAUXMIN, Z., Praxis Oratoria. Sive Praecaepta Artis Rhetoricae, quae ad componendam orationem scitu necessaria sunt, Monachii 1658. A rhetorical review of this handbook may be found i.a. in: BEDNARSKI, S., Upadek i odrodzenie..., op. cit, p. 192 et al. 
Regem ararij, vectigalium, Provincarum omnium, totius Reipubl. Regnorum, liberorum populorum, orbis denique terrarum Domini constituantur, legis agraria simulatione atque nomine.

- p. 58: Conferte hanc pacem cum illo bello: hujus Praetoris adventum cum illius Imperatoris victoria: cujus cohortem impuram, cum illius exercitu invicto: hujus libidines cum illius continentia: ab illlo, qui cepit conditas; ab hoc, qui constitutas accepit captas dicetis Syracusas.

- p. 60: Levia sunt haec in haec re crimina: metum virgarum Navarchus nobilissima Civitatis pretio redemit; humanum: alius ne condemnaretur pecuniam dedit; usitatum est. Non vult Pup. Rom. etc. [and the author's commentary:] Ex hoc fonte laudantur hostes, ut conillustrior Imperatoris virtus \& victoria appareat.

- p. 127:

IN GENERE IUDICIALI

QUAESTIO. Virum Aristodomus Spartanus, quod e praelio ad Thermopylas solus incolumis evasisset, puniendis sit. Herod. Lib. 7.

STATUS Est conjecturalis.

PROPOSITIO ET CAUSA.

ACTORIS. Puniendus est Aristodomus, $n$. 5.

PATRONI: Non est puniendus. N. 7. [afterwards a few pages of detailed analysis of the event]

- Rex Leonidas [...] necessarium esse videret, obsideri Thermopylas, ad arcendos a Graecia

Barbaros.

Obviously, the above-mentioned fragments are randomly selected, however, they already allow for drawing some conclusions. The authors of the handbooks, in order to illustrate the selected principle, would not create their own examples, but rather, they drew upon the rich, mostly antique, legacy (however, there is a number of curious examples of employing contemporary texts, or of describing the current political situation). Moreover, the examples were meticulously selected, in order to simultaneously "promote" values considered as worth promoting within education. Most of all, they would be related to virtuous life, dedication to the state, and the necessity to care for its setting and well-functioning (e.g. the frequent cases of treasury), the respect for law and the advantages of the life of gentry (also familiar to Romans). Aside from that, their task was to familiarise students with republican state principles, the basic principles of Roman law, as well as, obviously, expanding the erudition of students.

One should note the fact, that the number of sources, allowing the study of the role of history in Jesuit education, is impressive. Particular professors or students were to prepare lecture scripts of any type of research aids in order to master the art of oratory ${ }^{32}$. These sources exhibit the great role of history in the didactic process. One of the scripts (the above-mentioned Capitolium copiose loquentis) was written by the Jesuit College in Poznań in the years 1679-1680, dedicated to the school of rhetoric. With a degree of caution, one may state, that it was written by a professor of rhetoric, judging by the address on one of the first pages: ORATOR AUDITORI. In the following part of the text, the author addresses not an individual reader, but the "orators in spe". Therefore, one may as-

${ }^{32}$ Lately, a valuable collection of such aids has been prepared by: BIEŚ, A.P., Kadry nauczycielskie poznańskiego kolegium w XVI-XVIII wieku. Zarys problematyki, [in:] Wokół jezuickiej fundacji uniwersytetu z 1611 roku, ed. R. WITKOWSKI and D. ŻOŁĄDŹ-STRZELCZYK, Poznań 2011, p. $218-222$. 
sume, that we are dealing with a lecture script, however, clearly ordered in terms of content, where certain parts were deliberately selected.

The source material is vast and detailed. One may distinguish a number of clear parts. We shall examine the first of them, where we find particular issues, regarding the particular part of rhetorical theory and practical knowledge. Erudite remarks are most often vast, divided into Eruditio profana and sacra, however the distinction does not necessarily reflect the contents contained in particular fragments. The content is related to the history of the greatest Polish heraldic families, and simultaneously, with the history of Poland ${ }^{33}$. Heraldic parts are complemented by descriptions of various emblems, that would serve the purpose of constructing a narrative (Symbola). Aside from that, there is a number of separate sections called Discursus politicus, discussing selected issues regarding the functioning of the Polish state, e.g. the meaning of nobility, freedom, the matters of Royal Treasury, problematic issues regarding Royal elections, etc.

The first pages of the book, contain an example of a lecture, providing information helpful in preparing a speech for a heraldic occasion. First, the Habdank coat of arms is presented. The example describes the history of its bequest in a wide historical commentary, recalling the appropriate rulers of Poland, referring to the records by Długosz. After discussing the legendary history of the country, along with Krak, and the dragon-slaying tale at Wawel, a heraldic legend is presented, related to the Crisgova homage ${ }^{34}$ :

Anno 1109 vocatum est hoc stemma ex occasione Ioannis Skarbek Comitis a Boleslao Crivoustio ad Henricum Imperatorem nuntij cui Imperator ad debellandam Poloniam thesauros paratos ostendit, sed generos [...] legatus detractum digito annulum iniecit thesauro. Aurum inquiens addamus auro. Cuis Caesar respondit Habdank id esse gratias habeo.

After a detailed graphical description of the discussed coat of arms within the Eruditio profana section, a number of related poems is recalled, including the poem by Maciej Sarbiewski. Afterwards, the author, referring to the "W" letter present on the coat of arms, would explain the coming to be of the heraldic symbolic ${ }^{35}$ :

Lacedemonii scutis suis litteram L inscribebant. Messenij literam M. Romani omnia signa militaria prima litera nominis Ducis sui notabant. Ita Alexander ab Alexandro lib: 4 Cap: 2 ut Cingunt Poetae Mercurium primum fuisse inventorem sermonis humani et literarum [...]. Traianus Imperator globaratur sui nominis literas plurissimas fuisse. Hercules longioris peregrinationis causam dabat. Nomen Herculis quaero Ego a circumstantia stemmatis huius mentionem feci Illsmi Fundatoris Adami Konarski sed erige tandem sacris intumulatum cineribus caput Illrsime et Rndlissime Antistes Adame Konarski etiam te vel in emortuali meta manet laurea imo primas supremasque unam in flectemus in Coronam, qua Infulatum verticem omnium compendium decorum coronemus.

${ }^{33}$ Regarding the heraldic theme in the education in Jesuit schools, see: PUCHOWSKI, K., Edukacja historyczna..., op. cit, p. 62-64.

34 Capitolium Copiose loquentis..., op. cit, f. 7.

35 Ibidem, f. $7 \mathrm{v}$. 
As observed, the above example, primarily exhibits erudite value. We may only add the merit consisting of indicating the relations between the main heraldic families with the remote national tradition, which most certainly strengthened the national (estate) unity. Regarding the aforementioned, one should add that although currently the value of genealogical knowledge may seem minor, in the political and cultural situation of the times it was of considerable value and constituted a significant component of education. As noted by Sławomir Baczewski, since the turn of the $16^{\text {th }}$ century, the focus within the discussion regarding nobility, moved from the issues of duties of nobility to the Republic, to the heraldic-genealogical discourse. Raising such issues was meant to present the immutability and continuity of nobility, achieved by indicating the honoured ancestors and their contemporary heirs ${ }^{36}$, as well as legitimise the standing of nobility within the state and the society $^{37}$.

From the perspective of education, the "political discourses" seem to be of more interest. The first is dedicated to the Polish nobility (de Polona Nobilitate), which was defined as the greatness of a lineage, granted by the ruler by exhibiting exceptional virtues. Virtue was inseparably tied to nobility, both moral and knightly ${ }^{38}$. Therefore, the duties of nobility were defined: the defence of the Republic, and advice ${ }^{39}$, as well as, the demonstration of the righteousness of distinguishing nobility among the society. Among the arguments there was, i.a. a belief that the equality of citizens would lead to calamitous rivalry. In turn, as was demonstrated, the presence of nobility in empires such as Turkish or Chinese, contributed to the blooming of these countries. Similarly, among the Swiss and the Dutch. Aside from that, a number of examples from bygone history were presented. Interestingly, an argument is present, that equality of all estates was rejected by Jean Bodin in the third book of his work on the Republic. Additionally, the nobility was, in the opinion of the author, also legitimised by antiquity ${ }^{40}$ :

Probatur antiquitate nobilitatis. Nobilitas semper fuit in omni Republica bene constituta. Nam apud Israelitas erant Principes Nobiles et Optimates. Apud Aegyptios fuerunt varij Principes, apud Persos et Medos mali. Habuit Macedonia Nobiles, habuit Graecia, Athenisque ipsis Nobilibus Magistratum cura demandabatur. In Germania Imperij fulcrum Nobilitas. In Gallia Nobiles bella gerunt et Rempublicam administrant. Quid de nostra dicendum Polonia quae nisi Nobilitatem habuisset iam pridem suis involuta ruinis incinerata cladibus periisset.

${ }^{36}$ BACZEWSKI, S., Szlachectwo. Studium z dziejów idei w piśmiennictwie polskim. Druga połowa XVI wieku - XVII wiek, Lublin 2009, p. 144, 148 et al.

37 Ibidem, p. 238.

${ }^{38}$ Cf. Ibidem, p. 218.

39 Capitolium Copiose loquentis..., op. cit, f. 8 et al.: "Primum igitur et principale Nobilitatis fundamentum virtus est, eaquem aut civilis aut martialis; ideo enim aliquis creatus nobilis quia hostem fortiter oppressit; aliquodque opus strenuum est aggressus, vel quia consilio Rempublicam iuvit et erexit."

40 Ibidem, f. 9. 
The argumentation within the script is much vaster, however, there is no need to present it in extenso. Let us take notice, however, that the historical examples were used here, to strengthen the argument, drawing upon the significant value of tradition. The approach characterised by the regard towards the ancestors and the past, and even a certain respect, allowed for an educational influence on students with the use of history.

Additionally, the discussed script presents the historical genealogy of the shaping of the nobility law, beginning with the Statutes of Casimir the Great, regulating the criminal law regarding nobility, with a brief overview of principles. Afterwards, the Piotrków privileges issued by Sigismund III, confirming the privileges of the nobility, bestowing economic freedoms upon nobility in regard to the subjects and the crown, as well as granting nobility the sole right to take canonical and prelate offices in cathedral churches. Aside from that the privileges regarding the inviolability of the nobles, the sole right to bear the senate office, economic freedoms and the right to the election of the king, were discussed. One can clearly see, that during classes, youth was sensitised to the exceptional nature of the nobility (Pretium Polonae Nobilitatis), which was confirmed by the anecdote, presenting the concern of the Emperor Augustus regarding ensuring his daughter to be properly wed $^{41}$. The exceptional practicality of history for the education of noble youth, is striking here. The youth would not only receive the knowledge regarding their righteous privileges, but also information, where to look for their confirmation.

The subject of another discourse, is Polish freedom. It begins with a weighty statement, that freedom is valued above all, and for Poles, even above life. Following a general introduction, a specific apologia ensues, of the shaping of Polish freedom as a unique phenomenon, as it was acquired gradually and peacefully. Afterwards the author recalls the most important proceedings regarding the subject. The actions of Casimir the Great, Louis I of Hungary and Władysław II Jagiełło are taken into account. The issue is summarised by a quite vast description of the allegations towards "the golden freedom" as well as counter-arguments ${ }^{42}$.

Apart from political-social content, the script contains some interesting issues regarding economy education. In this context, one should mention the lecture concerning the Royal treasury: Thesaurus maximum Regnorum fulcrum ac praesidium. Quare Henricus Imperator non armis se Poloniam debellaturum iactabat, non ferro vastaturum sed auro thesauroque, quem iactabundus Poloniarum Legato praesentabat ${ }^{43}$. Continuing, the author of the lecture stated, that the Republic could not function without a treasury, just as gold cannot be without iron and vice versa. Sine thesauro Respublicam corpus ex anima est. Momentarily, an example of prince Bolesław appears, who was to show the riches of his treasury to the defeated knights. Afterwards, an issue of storing the entire state treasure in one place, is debated. The example of the biblical king Hezekiah, who after showing his treasures to the Assyrian legates, were to taunt king Sennacheribe into war, is pre-

\footnotetext{
${ }^{41}$ Ibidem, f. 9v-10v.

${ }^{42}$ Ibidem, f. $14 \mathrm{v}$ et al.

43 Ibidem, f. 22.
} 
sented as an argument against such practice. Afterwards, the practice of Ancient Egypt is presented, where the treasure was not to be stored, due to the lack of external threats, which would allow them to spend their funds on various buildings. Arguments for hoarding treasure and surrounding it with proper care, are discussed in more detail. The author refers, e.g. to the history of Sparta, Rome and Genoa. Characters are brought into the light, such as Romulus, Cato and the Emperor Augustus, who was to keep all the records of income and expenditures of the Empire, by himself. The Egyptian agriculture is mentioned, and how it was profitable for the treasury. The example of the king of France, Louis (probably Louis VII the Young) was also mentioned, as he, during the reign of the Emperor Alfonso VII, would venture to Toledo and be marvelled by its magnificence and the luxury, resulting from the care of the treasury, present neither in Europe nor in Asia ${ }^{44}$.

A supplement to the treatise contains a noteworthy collection of sentences from historical and rhetorical works regarding various subjects: timor, licentia puniendi mali, suprema potestas, animi victoria, sapientia est vincere seipsum, belli signum timor, iniuria, "a vastness of content, one cannot enumerate" (sic!), pax semper potior. These examples, presented in vast quantity, primarily indicate the significance of morality, a matter that seemed omitted in the previous section of the work. It is well known, that moral or religious education was at the centre of interest in Jesuit schools. However, in the context of discussing the role of historical education in the above-mentioned College, one should turn own attention to the selected plays of the Poznań School Theatre. There, the enormous role of the history of the time in the moral and patriotic formation of school youth, is explicit ${ }^{45}$.

The role of historical narrative in school education was manifold. In this particular case, the primary purpose was the patriotic and, in more general terms: civil education, providing students with solid grounds for functioning in the politics and the social reality of the time. Adding to that, the competence of students, regarding language and literary proficiency, we bear witness to a curious image of the graduates of the Polish school of the time. Students, within the framework of political discourses, received knowledge on the estate privileges, as well as duties weighing on the nobility. Mind, that history was also the means of passing actual knowledge regarding antique and Polish past, including the widely understood culture and various state-oriented issues. Knowledge gathered in school and due to own study of historical works, would in the future, serve as the grounds for practising the art of oration in the public life, as well as, an active and responsible governance of the Polish state. Additionally, let us take note, that erudition was the basis for

44 Ibidem, f. 22-23.

45 The matters of the Jesuit school theatre has been given much literary attention, therefore, the problem is only mentioned, see, i.a.: POPLATEK, J., Studia z dziejów jezuickiego teatru szkolnego w Polsce, Wrocław 1957; OKOŃ, J., Dramat i teatr szkolny. Sceny jezuickie XVII wieku, Wrocław 1970; OKON, J., Na scenach jezuickich w dawnej Polsce, Warsaw 2006; JUDKOWIAK, B., "Teatr i dramat jezuitów", Kronika Miasta Poznania, 2000, no. 3, p. 22-42; JUDKOWIAK, B., Kilka uwag na temat teatru poznańskich szkół jezuickich w kontekście ich starań o prawa uniwersyteckie, [in:] Wokót jezuickiej fundacji..., op. cit.; and lately: NOWICKI, M., "Edukacyjne walory publicznych występów poznańskiej młodzieży szkolnej w XVI-XVIII wieku", Studia Edukacyjne, 2011, vol. 15, p. 183-195. 
theatre plays, school dialogues and annual speeches. Without the proper training, nobles would be unable to participate in the cultural life of their era, by no means an elite, but rather "popular" life, obviously, narrowed down to nobility. Let the erudite assortment regarding Polish coats of arms serve as an example, including heraldic legends, descriptions of coats of arms, emblems (e.g. a hawk between columns, a hawk deprived of claws, etc. followed by appropriate sentences), but particularly the collections of historical facts, helpful in arranging speeches for heraldic annuals, both secular and sacral (eruditio sacra et profana).

As it seems, young people, owing to the "active" cognition of the past (by means of plays, speech arrangement or brief literary works), would receive thorough historical education, and although they did not not attend separate history classes, through the majority of the Old Polish Period, they possessed much greater competence in this subject, than our contemporary youth. Contemporary history is a particularly interesting example here, as the history of the time was given much attention, especially regarding the political situation of the Polish state. One should note, that the definitive majority of the contents of the work in question is focused on the matters of Poland and its history. World history plays a major role as well, however, it is mostly limited to providing arguments for a given hypothesis, or serves the role of exemplification of the selected issues.

\section{Bibliography}

Akta wizytacji 1660 - 1663, The Archidiocesan Archive in Poznań, sign. AV 12.

BACZEWSKI, S., Szlachectwo. Studium z dziejów idei w piśmiennictwie polskim. Druga połowa XVI wieku-XVII wiek, Lublin 2009.

BEDNARSKI, S., Upadek i odrodzenie szkót jezuickich w Polsce, Kraków 1933.

BIEŃKOWSKI, T., Szkolne wyksztatcenie retoryczne wobec wymogów praktyki (Uwagi o funkcji retoryki w Polsce $w$ XVI i XVII w.), [in:] Retoryka a literatura, ed. B. OTWINOWSKA, Wrocław 1984.

BIEŃKOWSKI, T., ,,Bibliotheca selecta de ratione studiorum” Possevina jako teoretyczny fundament kultury kontrreformacji, [in:] Wiek XVII - Kontrreformacja-Barok. Prace z historii kultury, ed. J. PELC, Wrocław 1970.

BIEŃKOWSKI, T., Antyk w literaturze i kulturze staropolskiej (1415-1750). Główne problemy i kierunki recepcji, Wrocław-Warsaw-Kraków-Gdańsk 1976.

BIEŃKOWSKI, T., Ksztaltowanie publiczności literackiej w szkołach w Polsce w XVI i XVII w., [in:] Publiczność literacka i teatralna $w$ dawnej Polsce, ed. H. DZIECHCIŃSKA, WarsawŁódź 1985.

BIEŚ, A.P., Kadry nauczycielskie poznańskiego kolegium w XVI-XVIII wieku. Zarys problematyki, [in:] Wokót jezuickiej fundacji uniwersytetu z 1611 roku, ed. R. WITKOWSKI and D. ŻOŁĄDŹ-STRZELCZYK, Poznań 2011.

Capitolium Copiose loquentis sapiae Avitis Poloniae Nobilitatum Stemmatibus Ceris fumosisque Maiorum illustre imaginibus Oratorum Calamo Ingenioque adumbratum ac Konarsciano in Academo Arhitectante Eloquentiae manu erectum ac reseratum Anno [...], 1679 Biblioteka Uniwersytecka w Poznaniu, rkps 588 I.

CICERO, M.T., De oratore ad Q. fratrem, Oxoniae post 1696.

JANICKI K., Vitae Regum Polonorum elegiaco carminae descriptae, Cracoviae 1569. 
JUDKOWIAK, B., "Teatr i dramat jezuitów”, Kronika Miasta Poznania, 2000, No. 3, p. 22-42.

JUDKOWIAK, B., Kilka uwag na temat teatru poznańskich szkót jezuickich w kontekście ich starań o prawa uniwersyteckie, [in:] Wokót jezuickiej fundacji uniwersytetu z 1611 roku, ed. R. WITKOWSKI and D. ŻOŁĄDŹ-STRZELCZYK, Poznań 2011.

KOT, S., Szkolnictwo parafialne w Matopolsce XVI-XVIII w., Lwów 1912.

LAUXMIN, Z., Praxis Oratoria. Sive Praecaepta Artis Rhetoricae, quae ad componendam orationem scitu necessaria sunt, Monachii 1658.

ŁUKASZEWICZ, J.,Historya szkót $w$ Koronie $i w$ Wielkiem Księstwie Litewskiem od najdawniejszych czasów aż do roku 1794, Poznań 1849, vol. I-III.

MOKRZECKI, L., Początki nauczania historii w okresie I Rzeczypospolitej na tle praktyki stosowanej w szkolnictwie europejskim, [in:] Wokót staropolskiej nauki i oświaty. Gdańsk-Prusy Królewskie-Rzeczpospolita, Gdańsk 2001.

MOKRZECKI., L., PUCHOWSKI, K., Pierwsi nauczyciele historii w szkolnictwie staropolskim, [in:] Nauczyciel historii. Ku nowej formacji dydaktycznej, ed. M. KUJAWSKA, Poznań 1996.

NATOŃSKI, B., Szkolnictwo jezuickie w Polsce w dobie kontrreformacji, [in:] Wiek XVII - Kontrreformacja-Barok. Prace z historii kultury, ed. J. PELC, Wrocław 1970.

NOWICKI, M., "Edukacyjne walory publicznych występów poznańskiej młodzieży szkolnej w XVI-XVIII wieku", Studia Edukacyjne, 2011, vol. 15, p. 183-195.

OKOŃ, J., Dramat i teatr szkolny. Sceny jezuickie XVII wieku, Wrocław 1970.

OKOŃ., J., Na scenach jezuickich $w$ dawnej Polsce, Warsaw 2006.

PIECHNIK, L., Działalność jezuitów polskich na polu szkolnictwa (1565-1773), [in:] Jezuici a kultura polska, ed. L. GRZEBIEŃ and S. OBIREK, Kraków 1993.

PIECHNIK, L., ,, Ratio studiorum”: fundament działalności edukacyjnej i naukowej jezuitów, [in:] Wkład jezuitów do nauki i kultury w Rzeczpospolitej Obojga Narodów i pod zaborami, ed. I. STASIEWICZ-JASIUKOWA, Kraków 2004.

PIECHNIK, L., Przemiany w szkolnictwie jezuickim w Polsce XVIII wieku, [in:] Z dziejów szkolnictwa jezuickiego w Polsce: wybór artykułów, ed. J. PASZENDA, Kraków 1994.

POPLATEK, J., Studia z dziejów jezuickiego teatru szkolnego w Polsce, Wrocław 1957.

PREJS, M., Humanizm potrydencki i nowy model kultury katolickiej (manieryzm czy barok?), [in:] Humanistyczne modele kultury nowożytnej wobec dziedzictwa starożytnego, ed. M. PREJS, Warsaw 2010.

PUCHOWSKI, K., Edukacja historyczna w jezuickich kolegiach Rzeczypospolitej 1565-1773, Gdańsk 1999.

QUINTILIANUS, M.F., Institutionis oratoriae libri XII, ed. L. RADEMARCHER, in Aedibus B.G. Tevbneri, Lipsiae 1959.

Ratio atque insitutio studiorum SJ czyli Ustawa szkolna Towarzystwa Jezusowego (1599), ed. K. BARTNICKA, Warsaw 2000.

Ratio atque institutio studiorum Societatis Iesu, Romae 1616. 